\title{
TINJAUAN HUKUM MENGENAI PERLINDUNGAN TENAGA KERJA INDONESIA DIHUBUNGKAN DENGAN PRINSIP STANDAR MIMUM INTERNASIONAL DALAM PERSPEKTIF HAK ASASI MANUSIA
}

\author{
Siti Sumartini \\ Universitas Wiralodra, Indramayu \\ Email: sitisumartini_unwir@yahooo.co.id
}

\begin{abstract}
Problems of Indonesian Workers (TKI) is never complete, this is caused by many factors that lie behind it. Cases of physical violence, unpaid salaries, sexual ravings to the death penalty of defending. can be drawn a legal issue that focuses as follows; What is the Shape of Protection Against TKIs working in other countries in a human rights perspective? and How can the International Minimum Standards Principle be applied as a form of protection to labor migrants?. This research is done by using normative juridical method. This juridical approach is due to this research by analyzing the legal aspects that exist, and is normative since this study focuses more on the analysis of existing legislation and other regulations, both from national and international perspectives, as well as using data secondary data that is scientific references or other scientific writings as a study material that can support the completeness of this scientific work. Legal protection regarding TKI is an absolute must be done by the Indonesian government, given the TKI is a foreign exchange hero for the country.
\end{abstract}

Key Word: Legal Protection, TKI, Human Rights Protection, International Minimum Standards.

\section{PENDAHULUAN}

Bangsa Indonesia adalah bangsa yang sedang membangun. Pembangunan yang sedang berjalan merupakan pembangunan yang bersifat menyeluruh (inklusif). Pembangunan merupakan upaya sistematis dan terencana oleh masing-masing maupun seluruh komponen bangsa untuk mengubah suatu keadaan menjadi keadaan yang lebih baik dengan cara memanfaatkan sumber daya yang tersedia secara optimal, efektif, efisien, dan akuntabel, sehingga dapat meningkatkan kualitas hidup masyarakat menjadi lebih sejahtera. Adapun pengertian dari Pembangunan Nasional adalah upaya yang dilaksanakan oleh semua komponen bangsa dalam rangka mencapai tujuan bernegara. Pembangunan Nasional itu sendiri diselenggarakan berdasarkan demokrasi dengan prinsip-prinsip 
kebersamaan, berkeadilan, berkelanjutan, berwawasan lingkungan, serta kemandirian dengan menjaga keseimbangan kemajuan dan kesatuan Nasional. ${ }^{1}$

Pembangunan yang sedang digalakan oleh bangsa kita pada kenyataannya masih menyisakan persoalan, khususnya mengenai perlindungan tenaga kerja. Hal ini dikarenakan Indonesia adalah salah satu pemasok tenaga kerja ke beberapa negara yang menggunakan jasa-jasa dari tenaga kerja kita. Sangat kontras dengan jargon pembangunan disegala bidang, ternyata negara kita belum mampu menyerap tenaga kerja yang tersedia secara optimal. Indonesia merupakan salah satu negara yang mengirimkan tenaga kerjanya ke luar negeri dalam jumlah yang besar. Besarnya jumlah tenaga kerja, tingginya jumlah pengangguran, serta minimnya lapangan kerja yang tersedia di Indonesia menjadi faktor pendukung peningkatan jumlah TKI yang bekerja ke luar negeri. Hal ini menjadi alternatif bagi Indonesia untuk mengurangi persoalan yang berkaitan dengan ketenagakerjaan di dalam negeri.

Pengiriman tenaga kerja ke luar negeri ini juga menjadi salah satu sumber devisa yang potensial bagi pertumbuhan perekonomian Indonesia. Laporan dari Badan Nasional Penempatan dan Perlindungan Tenaga Kerja Indonesia yang berasal dari Bank Indonesia enyatakan bahwa remittance tahun 2013 (hingga bulan November 2013) mencapai Rp 81,34 Triliun dengan asumsi nilai tukar Rp 11.000 per USD. ${ }^{2}$ Berdasarkan data dari BNP2TKI, Saudi Arabia menempati posisi pertama sebagai negara yang menerima TKI sejak tahun 2006 hingga tahun 2011. Meskipun demikian, Saudi Arabia juga menempati posisi pertama sebagai negara dengan tingkat pengaduan TKI yang tinggi. ${ }^{3}$ Konsulat Jenderal Republik Indonesia (KJRI) Jeddah mengatakan bahwa kasus yang terjadi di Saudi Arabia pada tahun 2010 sebanyak 1.546 kasus. ${ }^{4}$ Kasus yang terjadi tidak hanya kekerasan fisik, tetapi juga seperti kekerasan seksual, uang gaji yang bermasalah, overstayer, putusnya komunikasi dengan keluarga, tidak mendapatkan cuti ataupun libur, tidak diberikan akses kesehatan, kasus pembunuhan, dan berbagai kasus lainnya. Bahkan di Saudi Arabia, tidak jarang TKI dijatuhi hukuman mati dengan berbagai alasan dan ini Nasional.

${ }^{1}$ Pasa1 angka (2) Undang-Undang No.25 Tahun 2004 Tentang Sistem Perencanaan Pembangunan

2 BNP2TKI 2013, "Remitansi TKI Tahun 2013 Capai Rp 81,34 Trilyun”, diakses pada 30 Maret 2017,<http://www.bnp2tki.go.id/berita-mainmenu-231/9227-remitansi-tki-tahun-2013-capai-rp-8134trilyun.html $>$.

${ }^{3}$ Suprayogi, A 2013, "Malaysia dan Arab Saudi", Negara Kasus TKI Tertinggi, diakses pada 01 Januari 2017, <http://news.liputan6.com/read/624151/malaysia-dan-arab-saudi-negarakasus-tki-tertinggi>

${ }^{4}$ BNP2TKI 2011, "Turun, Penyelesaian Kasus TKI di Arab Saudi”, diakses pada 01 April 2017, html

<http://www.bnp2tki.go.id/berita-mainmenu-231/3953-turun-penyelesaian-kasus-tki-diarab-saudi. 
mengancam hak hidup TKI, seperti Yanti Iriyanti pada 12 Februari 2008 dan Ruyati pada 18 Juni 2011. Migrant Care menyatakan bahwa untuk tahun 2013 terdapat 42 kasus hukuman mati untuk TKI di Saudi Arabia, dimana 9 kasus diantaranya mendapatkan vonis tetap hukuman mati dan 33 kasus lainnya masih dalam proses. ${ }^{5}$ Seperti kasus yang menimpa Ruyati Ruyati adalah seorang TKW asal Bekasi, Jawa Barat di Arab Saudi yang membunuh majikannya. Dia berusaha membunuh ibu majikannya yang bernama Khairiyah Hamid yang berusia 64 tahun karena merasa tidak tahan dengan kekejamannya.

Undang-Undang No.39 tahun 2004 tentang Penempatan dan Perlindungan TKI di luar negeri telah melahirkan suatu badan atau lembaga yang khusus menangani masalah TKI yakni Badan Nasional Penempatan dan Perlindungan TKI (BNPPTKI). Namun demikian hingga saat ini lembaga tersebut belum mampu menerjemahkan keinginankeingainan dari unadng-undang tersebut secara konkrit.

Disamping itu Organisasi Perburuhan Internasional (International Labour Organisation/ILO) mendefinisikan seorang "pekerja migran", sebagai seseorang yang bermigrasi, atau telah bermigrasi dari satu negara ke negara lain, dengan sebuah gambaran bahwa orang tersebut akan dipekerjakan oleh seseorang yang bukan dirinya sendiri, termasuk siapapun yang biasanya diakui sebagai seorang migran, untuk bekerja. Karena dalam prakteknya buruh migran tersebut menyangkut 2 negara, maka pemerintah wajib ikut campur tangan dalam mengurusi masalah penempatan para calon buruh migran tersebut, oleh karena itulah dibuatnya beberapa regulasi yang mengatur masalah TKI. ${ }^{6}$

Disamping itu persolan yang harus dihadapai bangsa Indonesia dengan diterapkannya Masyarakat Ekonomi ASEAN (MEA) tahun 2015, perubahan struktural yang saat ini sedang dilakukan dalam perekonomian Indonesia kemungkinan besar akan dipercepat. Perubahan struktural ini membutuhkan perubahan peralihan permintaan akan keterampilan dan membutuhkan inovasi guna memperkuat produktivitas. Lembagalembaga pasar tenaga kerja, bersama mitra sosial, perlu memainkan peran proaktif, guna menekan biaya dan mendorong produktivitas. ${ }^{7}$

\footnotetext{
${ }^{5}$ Gunawan, R 2013, “Migrant Care: 256 TKI Terancam Hukuman Mati di Luar Negeri”, diakses pada 12 April 2017, <http://news.liputan6.com/read/786508/migrant-care-256-tkiterancamhukuman-mati-di-luar-negeri $>$

${ }^{6} \mathrm{http}: / /$ www.lbhyogyakarta.org/2016/05/perlindungan-negara-terhadap-buruh-migran diakses pada

${ }^{7}$ http://www.ilo.org/wcmsp5/groups/public/asiajakarta/documents/publication/wcms, diakses pada
} tanggal 07 April 2017. tangal 20Desember 2017 
Indonesia saat ini dalam tahap pembangunan di mana ia memiliki jumlah penduduk usia kerja yang lebih tinggi dibandingkan penduduk usia tua yang mandiri. Untuk mengoptimalkan manfaat yang terkait dengan rasio kemandirian yang rendah ini, pemerintah perlu memperluas investasinya di bidang pendidikan dan pelatihan keterampilan, terutama karena pekerja dengan latar belakangan pendidikan yang tinggi dapat menikmati upah yang lebih besar dan kesempatan kerja yang lebih baik. Hal ini sangat penting, karena ada bukti bahwa perekonomian Indonesia saat ini sedang mengalami kekurangan pekerja trampil dan kelebihan tenaga kerja.

Ada bukti bahwa permintaan akan pekerja dengan kualifikasi tinggi melampaui suplai tenaga kerja yang ada. Di samping itu, ada suplai tenaga kerja yang berlebihan untuk mereka yang memiliki latar belakang pendidikan SLTP dan SLTA Umum. Hal ini menimbulkan situasi di mana ada banyak lowongan kerja di Indonesia yang diisi pekerja yang kurang memenuhi syarat. Mengurangi insiden ketidakcocokan keterampilan merupakan hal yang penting untuk memperkuat daya saing dan produktivitas perekonomian Indonesia. Secara khusus, di saat negeri ini terus mengalami modernisasi, permintaan akan pekerja berpendidikan tinggi akan terus berkembang, sehingga saat ini diperlukan investasi di bidang pendidikan dan keterampilan yang tepat. Dan upaya untuk memperkuat balai latihan kerja (BLK), dan sistem magang, menjadi penting untuk menutup kesenjangan keterampilan ini. Di samping itu, kebijakan dan program yang memfasilitasi penempatan tenaga kerja juga merupakan faktor penting untuk mengoptimalkan pemanfaatan sumber daya manusia. ${ }^{8}$

Berdasarkan uraian latar belakang tersebut, maka dirumuskan permasalahan hukum sebagai berikut:

1. Bagaimanakah Bentuk Perlindungan Terhadap TKI yang bekerja di negara lain dari perspektif Hak Asasi Manusia?

2. Bagaimanakah Prinsip International Minimum Standar dapat diterapkan sebagai bentuk perlindungan terhadap TKI?

\section{METODE}

Negara hukum kesejahteraan akan selalu mepresentasikan dirinya dalam perubahan dan pembangunan. Pembangunan nasional dilaksanakan dalam rangka pembangunan manusia Indonesia seutuhnya dan pembangunan masyarakat Indonesia

8 Idem, hlm. 11. 
seluruhnya untuk mewujudkan masyarakat yang sejahtera, adil, makmur, yang merata, baik materiil maupun spiritual berdasarkan Pancasila dan Undang-Undang Dasar Negara Republik Indonesia Tahun 1945 Dalam pelaksanaan pembangunan nasional, tenaga kerja mempunyai peranan dan kedudukan yang sangat penting sebagai pelaku dan tujuan pembangunan. ${ }^{9}$

Dalam konteks negara hukum dan negara yang sedang membangun, akan sangat diperlukan sekali kontribusi hukum sebagai suatu kaedah sosial dimana kaedah tersebut tidak akan lepas dari persoalan nilai (value) yang berlaku dalam suatu masyarakat, Bahkan dapat dikatakan bahwa hukum yang baik adalah nilai-nilai yang berlaku dalam masyarakat dan nilai-nilai (values) tersebut adalah nilai yang seharusnya dimiliki oleh masyarakat yang sedang membangun, sehingga dapat dijelaskan bahwa hakikat pembangunan adalah masalah pembaharuan cara berpikir dan sikap yang hidup. ${ }^{10}$

Pembangunan dalam arti seluasnya-luasnya meliputi segala segi kehidupann masyarakat oleh karenanya peran dan fungsi hukum sebagai suatu pedoman dimaksudkan agar pembangunan yang sedang dilaksanakan tersebut berjalan dengan tertib dan memberikan rasa aman. Mochtar Kusumaatmadja mengatakan bahwa hukum merupakan sarana pembaharuan masyarakat. Peranan hukum dalam pembangunan adalah untuk menjamin bahwa perubahan itu terjadi dengan teratur. Perubahan maupun ketertiban (atau keteraturan) merupakan tujuan kembar dari masyarakat yang sedang membangun, dan hukum menjadi suatu alat yang tidak dapat diabaikan dalam proses pembangunan ${ }^{11}$

Pembangunan dipandang sebagai jembatan yang mampu merealisasikan negara hukum. Pembangunan dalam arti seluasnya-luasnya meliputi segala segi kehidupann masyarakat oleh karenanya peran dan fungsi hukum sebagai suatu pedoman dimaksudkan agar pembangunan yang sedang dilaksanakan tersebut berjalan dengan tertib dan memberikan rasa aman. ${ }^{12}$

Selanjutnya Indonesia sebagai bagian dari masyarakat internasional dan sesuai dengan Pembukaan Undang-Undang Dasar 1945, salah satu tujuan Pemerintah Negara Kesatuan Republik Indonesia adalah ikut melaksanakan ketertiban dunia yang berdasarkan kemerdekaan, perdamaian abadi dan keadilan sosial. Namun demikian pelaksanaan

\footnotetext{
${ }^{9}$ Konsideran Undang-Undang No. 13 Tahun 2003 tentang Ketenagakerjaan

10 Mochtar Kusumaatmadja, Konsep-Konsep Hukum Dalam Pembangunan, Bandung, Alumni, 2006, hlm. 10

${ }^{11}$ Ibid, hlm. 13-14.

${ }^{12}$ Mochtar Kusumatmadja,Op.cit, hlm.13
} 
kegiatan hubungan luar negeri, baik regional maupun internasional, melalui forum bilateral atau multilateral, diabdikan pada kepentingan nasional berdasarkan prinsip politik luar negeri yang bebas aktif. ${ }^{13}$

Negara dalam hukum internasional merupakan entitas yang utama dan merupakan subyek hukum internasional yang terpenting (par excellence) dibanding dengan subyeksubyek hukum internasional lainnya. Sebagai subyek hukum internasional negara memiliki hak-hak dan kewajiban menurut hukum internasional ${ }^{14}$. Disamping itu beberapa sarjana hukum internasional terkenal telah mengemukakan pendapatnya mengenai negara, seperti yang dinyatakan oleh J.L Brierly memberikan batasan mengenai negara sebagai suatu lembaga atau (institution) dan sebagai suatu wadah dimana manusia mencapai tujuan-tujuannya dan dapat melaksanakan kegiatan-kegiatannya. ${ }^{15}$

Adanya perbedaan kondisi dari negara-negara yang ada belahan dunia ini, dimana negara yang satu memiliki sumber daya alam dan sumber daya manusia yang berbeda dengan negara yang lainnya, hal inilah yang menyebabkan terjadinya hubungan internasional. Suatu negara dalam rangka melaksanakan pembangunan tidak mungkin dilakukan sendiri tanpa bantuan negara lain dan sebagai bagian dari masyarakat bangsabangsa seyogyanya negara harus bekerjasama dengan bangsa-bangsa lain, hal ini dilakukan dalam upaya untuk memenuhi kebutuhan nasional negaranya.

Saling membutuhkan antara bangsa-bangsa dipelbagai bidang kehidupan yang mengakibatkan timbulnya hubungan yang tetap dan terus menerus antara bangsa-bangsa mengakibatkan pula timbulnya kepentingan untuk memelihara dan mengatur hubungan yang demikian, karena hubungan antar negara adalah hubungan yang sifatnya timbal balik, maka dirasakan sangat penting untuk menjaga dan mengatur hubungan yang bermanfaat tersebut karena hal demikian juga merupakan kepentingan bersama. ${ }^{16}$

Praktek negara-negara dalam hal pemberian ijin masuk orang asing di wilayah negaranya, selalu disertai dengan persyaratan-persyaratan tertentu yang diatur dalam hukum nasional masing-masing negara. Tindakan ini sesuai dengan pencerminan dari prinsip kedaulatan negara yang dianut oleh suatu negara. Naumn demikian prinsip kedaulatan negara tidak boleh bertentangan dengan hukum internasional. Selanjunya

\footnotetext{
${ }^{13}$ Konsideran Undang-Undang No.37 Tahun 1999 tentang Hubungan Luar Negeri.

${ }^{14}$ Huala Adolf, Aspek-Aspek Negara dalam Hukum Internasional,Jakarta, RajaGrafindo Persada, 1996,hlm.1

15 J.L Brierly, The Law of Nations, Oxford, Clarendon Press, edisi ke-5, 1954, hlm.118

16 Mochtar Kusumaatmadja, Pengantar Hukum Internasionl, Jakarta, Putra Abardin, 1982,hlm.9
} 
perlindungan terhadap orang asing atau warga negara asing juga telah diatur didalam konevensi internasional Seorang asing berhak atas perlindungan yang sama berdasarkan undang-undang negara tempat ia berada dan berhak pula atas hak-hak tertentu untuk memberikan kemungkinan kepadanya hidup secara layak, seperti diatur pada pasal 9 Konvensi Montevideo Tahun 1933, yang berbunyi:"Nationals and foreigners are under the same protection of law and the national authorities and the foreigners may not claim right other or more than those of nationals".

Hal ini dapat sejalan dengan prinsip International Minimum Standard. Pandangan ini dianut oleh negara-negara maju, menurut pendapat ini dalam memperlakukan orang asing yang berada didalam yurisdiksi teritorial suatu negara (di dalam negeri) harus memenuhi standar minimum internasional, yaitu sesuai dengan hukum internasional dan perlindungan yang efektif menurut hukum internasional. Sebenarnya Pada prinsipnya setiap negara akan bertanggung jawab untuk memberikan perlindungan hukum kepada setiap warga negaranya dimanapun ia berada dan orang asing akan mendapat perlindungan hukum, dalam pembatasan-pembatasan tertentu, baik dari negara tempat sementara ia berada dan dari negara asalnya. Jika suatu negara tidak memebrikan perlindngan terhadap warga negara negara asing sesuai dengan kaidah-kaidah Internasional standar minum maka akan melahirkan tanggung jawab negara.

Persoalan ketenagakerjaan dalam perspektif hukum internasional juga telah diatur dalam beberapa traktak (perjanjian internasional) salah satunya adalah Ada banyak traktat internasional yang mengatur hak buruh migran, yang terakhir adalah The International Convention on The Protection of The Rights of All Migrant Workers and Members of Their Families, (Konvensi Internasional Mengenai Perlindungan Hak-Hak Seluruh Pekerja Migran Dan Anggota Keluarganya) yang dikeluarkan oleh PBB tahun 2003 sebagai hukum internasional. Konvensi ini telah diratifikasi oleh 43 negara, dan Indonesia pada tahun 2012 lalu telah meratifikasinya dengan mengesahkan Undang-Undang Nomor 6 Tahun 2012. Meski Indonesia telah meratifikasi, namun belum terlihat langkah-langkah nyata untuk memperbarui berbagai peraturan perundang-undangan terkait dengan perlindungan buruh migran untuk diselaraskan dengan konten konvensi. ${ }^{17}$

Secara yuridis konstitusional persoalan mengenai ketenagakerjaan telah diatur dalam Pasal 27 Ayat (2) Undang-Undang Dasar Tahun 1945, dikatakan bahwa Tiap-tiap warga negara berhak atas pekerjaan dan penghidupan yang layak bagi kemanusiaan,

\footnotetext{
${ }^{17} \mathrm{Ibid}$, http://www.lbhyogyakarta.org/2016/05/perlindungan-negara-terhadap-buruh-migran,
} 
selanjutnya lebih dipertegas lagi dalam definisi tenaga kerja menurut Undang-Undang No.13 tahun 2003 tentang Ketenagakerjaan menjelaskan bahwa Tenaga Kerja adalah "setiap orang yang mampu melakukan pekerjaan guna menghasilkan barang dan/atau jasa baik untuk memenuhi kebutuhan sendiri maupun untuk masyarakat."18 Selanjunyta dalam undang-undang yang sama dalam Pasal 13 juga dijelaskan bahwa setiap tenaga kerja mempunyai hak dan kesempatan yang sama untuk memilih, mendapatkan, atau pindah pekerjaan dan memperoleh penghasilan yang layak di dalam atau di luar negeri.

Tenaga kerja Indonesia di luar negeri sering dijadikan obyek perdaganga manusia, termasuk perbudakan dan kerja paksa, korban kekerasan, kesewenang-wenangan, kejahatan atas harkat dan martabat manusia, serta perlakuan lain yang melanggar hak asasi manusia dan dalam hal ini negara wajib menjamin dan melindungi hak asasi warga negaranya yang bekerja baik di dalam maupun di luar negeri berdasarkan prinsip persamaan hak, demokrasi, keadilan sosial,kesetaraan dan keadilan gender, anti diskriminasi, dan anti perdagangan manusia. ${ }^{19}$

Sementara pengertian dari Tenaga Kerja Indonesia menurut Peraturan Pemerintah No.3 Tahun 2013 tentang Perlindungan Tenaga Kerja Indonesia di Luar Negeri adalah setiap warga negara Indonesia yang memenuhi syarat untuk bekerja di luar negeri dalam hubungan kerja untuk jangka waktu tertentu dengan menerima upah. Selanjutnya bentuk upaya perlindungan terhadap TKI itu sendiri adalah segala upaya untuk melindungi kepentingan calon TKI atau TKI dalam mewujudkan terjaminnya pemenuhan hak-haknya sesuai dengan peraturan perundang-undangan, baik sebelum, selama, maupun sesudah bekerja. $^{20}$

Sebagai suatu negara hukum, pemerintah (negara) wajib melindungi seluruh warga negara Indonesia dari segala bentuk penjajahan dan ancaman. Namun, diakui juga bahwasannya penegakkan hukum masih sangat lemah, sehingga para pejabat dari instansi pemerintah serta oknum aparat keamanan ikut terlibat dalam tindak pidana perdagangan orang tersebut. Dalam hal ini Pemerintah, Pemerintah Daerah, masyarakat, dan keluarga wajib mencegah terjadinya tindak pidana perdagangan orang. Selanjutnya diharapkan Pemerintah dan Pemerintah Daerah dapat membuat suatu kebijakan, program, kegiatan, dan mengalokasikan anggaran untuk melaksanakan pencegahan dan penanganan

\footnotetext{
${ }^{18}$ Pasal 1 Undang-Undang no.13 tahun 2003 tentang Ketenagakerjaan

${ }^{19}$ Konsideran Undang-Undang No.39 tahun 2004 tentang Penempatan dan Perlindungan Tenaga Kerja Indonesia di Luar Negeri.

${ }^{20}$ Pasal 1 PP No.3 tahun 2013 tentang Perlindungan Tenaga kerja Indonesia di Luar Negeri
} 
masalah perdagangan orang. Adapun menurut Pasal 58 Undang-Undang No.21 Tahun 2007 tentang Tindak Pidana perdagangan Orang menjelaskan bahwa untuk melaksanakan pemberantasan tindak pidana perdagangan orang, Pemerintah dan Pemerintah Daerah wajib mengambil langkah-langkah untuk pencegahan dan penanganan tindak pidana perdagangan orang.

Penelitian ini menggunakan metode pendekatan Yuridis Normatif, yaitu penelitian dengan pendekatan yang lebih ditekankan pada data-data sekunder berupa bahan-bahan hukum primer, sekunder maupun tersier. Pada penelitian hukum normatif, bahan pustaka merupakan data dasar dalam (ilmu) penelitian yang digolongkan sebagai data sekunder. ${ }^{21}$ Spesifikasi penelitian ini adalah deskriptif analitis, yaitu penelitian yang bertujuan menggambarkan mengenai fakta-fakta disertai analisis yang akurat mengenai peraturan perundang-undangan yang berlaku baik nasional maupun internasional dihubungkan dengan teori-teori hukum yang berkaitan dengan pembangunan hukum.

\section{PEMBAHASAN}

Negara hukum kesejahteraan akan selalu mepresentasikan dirinya dalam perubahan dan pembangunan. Pembangunan nasional dilaksanakan dalam rangka pembangunan manusia Indonesia seutuhnya dan pembangunan masyarakat Indonesia seluruhnya untuk mewujudkan masyarakat yang sejahtera, adil, makmur, yang merata, baik materiil maupun spiritual berdasarkan Pancasila dan Undang-Undang Dasar Negara Republik Indonesia Tahun 1945 Dalam pelaksanaan pembangunan nasional, tenaga kerja mempunyai peranan dan kedudukan yang sangat penting sebagai pelaku dan tujuan pembangunan. ${ }^{22}$

Dalam konteks negara hukum dan negara yang sedang membangun, akan sangat diperlukan sekali kontribusi hukum sebagai suatu kaedah sosial dimana kaedah tersebut tidak akan lepas dari persoalan nilai (value) yang berlaku dalam suatu masyarakat, Bahkan dapat dikatakan bahwa hukum yang baik adalah nilai-nilai yang berlaku dalam masyarakat dan nilai-nilai (values) tersebut adalah nilai yang seharusnya dimiliki oleh masyarakat

${ }^{21}$ Soerjono Soekanto dan Sri Maudji, Penelitian Hukum Normatif Suatu Tinjauan Singkat, Jakarta: Raja Grafindo Persada, 1985, hlm 24

${ }^{22}$ Konsideran Undang-Undang No. 13 Tahun 2003 tentang Ketenagakerjaan 
yang sedang membangun, sehingga dapat dijelaskan bahwa hakikat pembangunan adalah masalah pembaharuan cara berpikir dan sikap yang hidup. ${ }^{23}$

Pembangunan dalam arti seluasnya-luasnya meliputi segala segi kehidupann masyarakat oleh karenanya peran dan fungsi hukum sebagai suatu pedoman dimaksudkan agar pembangunan yang sedang dilaksanakan tersebut berjalan dengan tertib dan memberikan rasa aman. Mochtar Kusumaatmadja mengatakan bahwa hukum merupakan sarana pembaharuan masyarakat. Peranan hukum dalam pembangunan adalah untuk menjamin bahwa perubahan itu terjadi dengan teratur. Perubahan maupun ketertiban (atau keteraturan) merupakan tujuan kembar dari masyarakat yang sedang membangun, dan hukum menjadi suatu alat yang tidak dapat diabaikan dalam proses pembangunan ${ }^{24}$

Pembangunan dipandang sebagai jembatan yang mampu merealisasikan negara hukum. Pembangunan dalam arti seluasnya-luasnya meliputi segala segi kehidupann masyarakat oleh karenanya peran dan fungsi hukum sebagai suatu pedoman dimaksudkan agar pembangunan yang sedang dilaksanakan tersebut berjalan dengan tertib dan memberikan rasa aman. ${ }^{25}$

Selanjutnya Indonesia sebagai bagian dari masyarakat internasional dan sesuai dengan Pembukaan Undang-Undang Dasar 1945, salah satu tujuan Pemerintah Negara Kesatuan Republik Indonesia adalah ikut melaksanakan ketertiban dunia yang berdasarkan kemerdekaan, perdamaian abadi dan keadilan sosial. Namun demikian pelaksanaan kegiatan hubungan luar negeri, baik regional maupun internasional, melalui forum bilateral atau multilateral, diabdikan pada kepentingan nasional berdasarkan prinsip politik luar negeri yang bebas aktif. ${ }^{26}$

Negara dalam hukum internasional merupakan entitas yang utama dan merupakan subyek hukum internasional yang terpenting (par excellence) dibanding dengan subyeksubyek hukum internasional lainnya. Sebagai subyek hukum internasional negara memiliki hak-hak dan kewajiban menurut hukum internasiona ${ }^{27}$. Disamping itu beberapa sarjana hukum internasional terkenal telah mengemukakan pendapatnya mengenai negara, seperti yang dinyatakan oleh J.L Brierly memberikan batasan mengenai negara sebagai

${ }^{23}$ Mochtar Kusumaatmadja, Konsep-Konsep Hukum Dalam Pembangunan, Bandung, Alumni, 2006, hlm. 10

${ }^{24}$ Ibid, hlm. 13-14.

${ }^{25}$ Mochtar Kusumatmadja,Op.cit, hlm.13

${ }^{26}$ Konsideran Undang-Undang No.37 Tahun 1999 tentang Hubungan Luar Negeri.

${ }^{27}$ Huala Adolf, Aspek-Aspek Negara dalam Hukum Internasional,Jakarta, RajaGrafindo Persada, 1996,hlm. 1 
suatu lembaga atau (institution) dan sebagai suatu wadah dimana manusia mencapai tujuan-tujuannya dan dapat melaksanakan kegiatan-kegiatannya. ${ }^{28}$

Adanya perbedaan kondisi dari negara-negara yang ada belahan dunia ini, dimana negara yang satu memiliki sumber daya alam dan sumber daya manusia yang berbeda dengan negara yang lainnya, hal inilah yang menyebabkan terjadinya hubungan internasional. Suatu negara dalam rangka melaksanakan pembangunan tidak mungkin dilakukan sendiri tanpa bantuan negara lain dan sebagai bagian dari masyarakat bangsabangsa seyogyanya negara harus bekerjasama dengan bangsa-bangsa lain, hal ini dilakukan dalam upaya untuk memenuhi kebutuhan nasional negaranya.

Saling membutuhkan antara bangsa-bangsa dipelbagai bidang kehidupan yang mengakibatkan timbulnya hubungan yang tetap dan terus menerus antara bangsa-bangsa mengakibatkan pula timbulnya kepentingan untuk memelihara dan mengatur hubungan yang demikian, karena hubungan antar negara adalah hubungan yang sifatnya timbal balik, maka dirasakan sangat penting untuk menjaga dan mengatur hubungan yang bermanfaat tersebut karena hal demikian juga merupakan kepentingan bersama. ${ }^{29}$

Praktek negara-negara dalam hal pemberian ijin masuk orang asing di wilayah negaranya, selalu disertai dengan persyaratan-persyaratan tertentu yang diatur dalam hukum nasional masing-masing negara. Tindakan ini sesuai dengan pencerminan dari prinsip kedaulatan negara yang dianut oleh suatu negara. Naumn demikian prinsip kedaulatan negara tidak boleh bertentangan dengan hukum internasional. Selanjunya perlindungan terhadap orang asing atau warga negara asing juga telah diatur didalam konevensi internasional Seorang asing berhak atas perlindungan yang sama berdasarkan undang-undang negara tempat ia berada dan berhak pula atas hak-hak tertentu untuk memberikan kemungkinan kepadanya hidup secara layak, seperti diatur pada pasal 9 Konvensi Montevideo Tahun 1933, yang berbunyi:"Nationals and foreigners are under the same protection of law and the national authorities and the foreigners may not claim right other or more than those of nationals".

Hal ini dapat sejalan dengan prinsip International Minimum Standard. Pandangan ini dianut oleh negara-negara maju, menurut pendapat ini dalam memperlakukan orang asing yang berada didalam yurisdiksi teritorial suatu negara (di dalam negeri) harus memenuhi standar minimum internasional, yaitu sesuai dengan hukum internasional dan

28 J.L Brierly, The Law of Nations, Oxford, Clarendon Press, edisi ke-5, 1954, hlm.118

29 Mochtar Kusumaatmadja, Pengantar Hukum Internasionl, Jakarta, Putra Abardin, 1982,hlm.9 
perlindungan yang efektif menurut hukum internasional. Sebenarnya Pada prinsipnya setiap negara akan bertanggung jawab untuk memberikan perlindungan hukum kepada setiap warga negaranya dimanapun ia berada dan orang asing akan mendapat perlindungan hukum, dalam pembatasan-pembatasan tertentu, baik dari negara tempat sementara ia berada dan dari negara asalnya. Jika suatu negara tidak memebrikan perlindngan terhadap warga negara negara asing sesuai dengan kaidah-kaidah Internasional standar minum maka akan melahirkan tanggung jawab negara.

Persoalan ketenagakerjaan dalam perspektif hukum internasional juga telah diatur dalam beberapa traktak (perjanjian internasional) salah satunya adalah Ada banyak traktat internasional yang mengatur hak buruh migran, yang terakhir adalah The International Convention on The Protection of The Rights of All Migrant Workers and Members of Their Families, (Konvensi Internasional Mengenai Perlindungan Hak-Hak Seluruh Pekerja Migran Dan Anggota Keluarganya) yang dikeluarkan oleh PBB tahun 2003 sebagai hukum internasional. Konvensi ini telah diratifikasi oleh 43 negara, dan Indonesia pada tahun 2012 lalu telah meratifikasinya dengan mengesahkan Undang-Undang Nomor 6 Tahun 2012. Meski Indonesia telah meratifikasi, namun belum terlihat langkah-langkah nyata untuk memperbarui berbagai peraturan perundang-undangan terkait dengan perlindungan buruh migran untuk diselaraskan dengan konten konvensi. ${ }^{30}$

Secara yuridis konstitusional persoalan mengenai ketenagakerjaan telah diatur dalam Pasal 27 Ayat (2) Undang-Undang Dasar Tahun 1945, dikatakan bahwa Tiap-tiap warga negara berhak atas pekerjaan dan penghidupan yang layak bagi kemanusiaan, selanjutnya lebih dipertegas lagi dalam definisi tenaga kerja menurut Undang-Undang No.13 tahun 2003 tentang Ketenagakerjaan menjelaskan bahwa Tenaga Kerja adalah "setiap orang yang mampu melakukan pekerjaan guna menghasilkan barang dan/atau jasa baik untuk memenuhi kebutuhan sendiri maupun untuk masyarakat." 31 Selanjunyta dalam undang-undang yang sama dalam Pasal 13 juga dijelaskan bahwa setiap tenaga kerja mempunyai hak dan kesempatan yang sama untuk memilih, mendapatkan, atau pindah pekerjaan dan memperoleh penghasilan yang layak di dalam atau di luar negeri.

Tenaga kerja Indonesia di luar negeri sering dijadikan obyek perdaganga manusia, termasuk perbudakan dan kerja paksa, korban kekerasan, kesewenang-wenangan, kejahatan atas harkat dan martabat manusia, serta perlakuan lain yang melanggar hak asasi

\footnotetext{
${ }^{30} \mathrm{Ibid}$, http://www.lbhyogyakarta.org/2016/05/perlindungan-negara-terhadap-buruh-migran,

${ }^{31}$ Pasal 1 Undang-Undang no.13 tahun 2003 tentang Ketenagakerjaan
} 
manusia dan dalam hal ini negara wajib menjamin dan melindungi hak asasi warga negaranya yang bekerja baik di dalam maupun di luar negeri berdasarkan prinsip persamaan hak, demokrasi, keadilan sosial,kesetaraan dan keadilan gender, anti diskriminasi, dan anti perdagangan manusia. ${ }^{32}$

Sementara pengertian dari Tenaga Kerja Indonesia menurut Peraturan Pemerintah No.3 Tahun 2013 tentang Perlindungan Tenaga Kerja Indonesia di Luar Negeri adalah setiap warga negara Indonesia yang memenuhi syarat untuk bekerja di luar negeri dalam hubungan kerja untuk jangka waktu tertentu dengan menerima upah. Selanjutnya bentuk upaya perlindungan terhadap TKI itu sendiri adalah segala upaya untuk melindungi kepentingan calon TKI atau TKI dalam mewujudkan terjaminnya pemenuhan hak-haknya sesuai dengan peraturan perundang-undangan, baik sebelum, selama, maupun sesudah bekerja. $^{33}$

Sebagai suatu negara hukum, pemerintah (negara) wajib melindungi seluruh warga negara Indonesia dari segala bentuk penjajahan dan ancaman. Namun, diakui juga bahwasannya penegakkan hukum masih sangat lemah, sehingga para pejabat dari instansi pemerintah serta oknum aparat keamanan ikut terlibat dalam tindak pidana perdagangan orang tersebut. Dalam hal ini Pemerintah, Pemerintah Daerah, masyarakat, dan keluarga wajib mencegah terjadinya tindak pidana perdagangan orang. Selanjutnya diharapkan Pemerintah dan Pemerintah Daerah dapat membuat suatu kebijakan, program, kegiatan, dan mengalokasikan anggaran untuk melaksanakan pencegahan dan penanganan masalah perdagangan orang. Adapun menurut Pasal 58 Undang-Undang No.21 Tahun 2007 tentang Tindak Pidana perdagangan Orang menjelaskan bahwa untuk melaksanakan pemberantasan tindak pidana perdagangan orang, Pemerintah dan Pemerintah Daerah wajib mengambil langkah-langkah untuk pencegahan dan penanganan tindak pidana perdagangan orang.

\subsection{Bentuk Perlindungan Terhadap TKI Yang Bekerja di Negara Lain}

Negara dan hukum dalam perkembangan ajaran tentang negara dewasa ini adalah dua hal yang dianggap ideal, yang mampu memberikan perlindungan terhadap rakyatnya. Negara hukum senantiasa digunakan sebagai dasar penyelenggaraan negara dalam satu sistem ketetatanegaraan tertentu yang tercermin atau termuat daalam norma-norma

\footnotetext{
${ }^{32}$ Konsideran Undang-Undang No.39 tahun 2004 tentang Penempatan dan Perlindungan Tenaga Kerja Indonesia di Luar Negeri.

${ }^{33}$ Pasal 1 PP No.3 tahun 2013 tentang Perlindungan Tenaga kerja Indonesia di Luar Negeri
} 
konstitusi masing-masing negara. Beberapa negara secara eksplisit menyebut prinsip negara hukum dalam konstitusinya, seperti misalnya Indonesia, disamping itu ada beberapa negara yang yang tidak secara eksplisit menyebutkan didalam konstitusinya namun lebih jauh akan terelaborasi (diperluas) di dalam pasal-pasal atau ketentuanketentuan hhukum yang berkaitan dengan identitas dirinya sebagai suatu negara hukum. Dalam kerangka tersebut konstitusi atau undang-undang dasar memainkan peran yang penting. ${ }^{34}$

Kesadaran umum mengenai hak-hak dan kewajiban asasi manusia itu menjiwai keseluruhan sistem hukum dan konstitusi Indonesia, oleh karena itu perlu diadopsikan kedalam rumusan Undang-Undang Dasar atas pengertian-pengertian dasar yang dikembangkan sendiri oleh bangsa indonesia. Sehingga dengan demikian perumusannya dalam Undang-Undang Dasar ini mencakup warisan-warisan pemikiran yang masih terus akan berkembang dimasa-masa yang akan datang.

Dari uraian diatas terlihat jelas hubungan antara negara hukum dan hak asasi manusia, hubungan mana bukan hanya dalam bentuk formal semata-mata, dalam arti bahwa perlindungan hak asasi manusia merupakan cirri utama konsep negara hukum, tapi juga hubungan tersebut dilihat secara materil. Hubungan secara materil ini dilukiskan atau digambarkan dengan setiap sikap tindak penyelenggara negara harus bertumpuh pada aturan hukum sebagai asas legalitas. Konstruksi yang demikian ini menunjukan pada hakekatnya semua kebijakan dan sikap tindak penguasa bertujuan untuk melindungi hak asasi manusia. Pada sisi lain, kekuasaan kehakiman yang bebas dan merdeka, tanpa dipengaruhi oleh kekuasaan manapun, merupakan wujud perlindungan dan penghormatan terhadap hak asasi manusia dalam negara hukum.

Hukum menjamin bahwa setiap tenaga kerja mempunyai hak kesempatan yang sama untuk memilih, mendapatkan, atau pindah pekerjaan dan memperoleh penghasilan yang layak di dalam atau di luar negeri. Penempatan TKI ke luar negeri, merupakan program nasional dalam upaya meningkatkan kesejahteraan tenaga kerja dan keluarganya serta pengembangan kualitas sumber daya manusia. Kebijakan dan program pemerintah mengenai penempatan Tenaga Kerja Indonesia (TKI) ke luar negeri merupakan salah satu solusi untuk mengurangi tingkat pengangguran di tanah air, dengan memanfaatkan kesempatan kerja di luar negeri, TKI tidak saja mendapatkan penghasilan yang cukup

${ }^{34}$ Susi Dwi Harijanti, Negara Hukum dan Ketatanegaraan (Dalam Tulisan Negara Hukum Yang Berkeadilan (Kumpulan Pemikiran) Dalam Rangka Purnabhakti Prof,Dr, H Bagir Manan, SH, MCL, Bandung, PSKN-HTN UNPAD-Rosda,2011, hlm.57. 
besar, tetapi juga ikut menyumbang devisa bagi negara Indonesia.Banyak TKI yang sudah berhasil, tetapi tidak sedikit pula yang pada mulanya ingin bekerja untuk membebaskan diri dan keluarganya dari jeratan kemiskinan mengalami penganiayaan dan perkosaan oleh majikan dan tindakan tidak semena-mena oleh sebagian perusahaan jasa tenaga kerja swasta.

Aspek perlindungan terhadap penempatan tenaga kerja di luar negeri sangat terkait pada sistem pengelolaan dan pengaturan yang dilakukan berbagai pihak yang terlibat pada pengiriman tenaga kerja Indonesia keluar negeri. Untuk langkah penempatan tenaga kerja di luar negeri, Indonesia telah menetapkan mekanisme melalui tiga fase tanggung jawab penempatan yakni fase pra penempatan, selama penempatan dan purna penempatan. Pengaturan tentang penempatan tenaga kerja Indonesia ke luar negeri adalah UndangUndang No. 39 Tahun 2004 Tentang Penempatan Dan Perlindungan Tenaga Kerja Indonesia Di Luar Negeri.

Penempatan TKI dilakukan dengan memanfaatkan pasar kerja internasional melalui peningkatan kualitas kompetensi tenaga kerja dengan perlindungan yang optimal sejak sebelum keberangkatan, selama bekerja di luar negeri sampai tiba kembali di Indonesia.

Dalam melaksanakan tugasnya sudah banyak TKI yang terlibat kasus penyiksaan. Tidak terdapat perubahan atas berbagai kasus sebelumnya yang terjadi, justru belakangan kasus penyiksaan TKI semakin meningkat. Pemerintah seolah tidak belajar atas kesalahankesalahan dimana terjadinya kasus yang sama sebelumnya. Seakan-akan sudah merupakan hal yang lumrah apabila terjadinya penyiksaan TKI setiap tahun. Disebutkan sudah terdapat regulasi yang mengatur mengenai perlindungan atas penempatan TKI. Tetapi faktanya kasus-kasus yang sama tetap saja terjadi dan tidak grafiknya tidak menurun justru meningkat. Perlu dipertanyakan kinerja pemerintah dalam penanganan berbagai persoalan yang telah terjadi sebelumnya

Di dalam pasal 80 Undang-Undang Nomor 39 Tahun 2004 dinyatakan bahwa Perlindungan selama masa penempatan TKI di luar negeri dilaksanakan antara lain:

1) Pemberian bantuan hukum sesuai dengan ketentuan peraturan perundangundangan di negara tujuan serta hukum dan kebiasaan internasional.

2) Pembelaan atas pemenuhan hak-hak sesuai dengan perjanjian kerja dan/atau peraturan perundang-undangan di negara TKI ditempatkan. Mengenai hak-hak para buruh migran Pasal 8 Undang-undang nomor 39 tahun 2004 menyatakan bahwa setiap calon TKW/TKI mempunyai hak dan kesempatan yang sama untuk: 
a) bekerja di luar negeri;

b) memperoleh informasi yang benar mengenai pasar kerja luar negeri dan prosedur penempatan TKI di luar negeri

c) memperoleh pelayanan dan perlakuan yang sama dalam penempatan di luar negeri;

d) memperoleh kebebasan menganut agama dan keyakinannya serta kesempatan untuk menjalankan ibadah sesuai dengan agama dan keyakinan yang dianutnya;

e) memperoleh upah sesuai dengan standar upah yang berlaku di negara tujuan;

f) memperoleh hak, kesempatan, dan perlakuan yang sama yang diperoleh tenaga kerja asing lainnya sesuai dengan peraturan perundangundangan di negara tujuan;

g) memperoleh jaminan perlindungan hukum sesuai dengan peraturan perundang-undangan atas tindakan yang dapat merendahkan harkat dan martabatnya serta pelanggaran atas hak-hak yang ditetapkan sesuai dengan peraturan perundang-undangan selama penempatan di luar negeri;

h) memperoleh jaminan perlindungan keselamatan dan keamanan kepulangan TKI ke tempat asal

Hal lain yang tidak kalah pentingnya peran pemerintah dalam melindungi Tenaga Kerja Indonesia. Mengesampingkan berbagai kasus mengenai penganiayaan atas TKI yang sudah terjadi. Di Indonesia telah disusun dalam bentuk undang-undang yang memuat regulasi penempatan TKI. Sudah terdapat ketentuan yang jelas, meskipun fakta dilapangan masih terdapat berbagai pelanggaran. Adapun dilakukannya penempatan TKI keluar negeri merupakan upaya dalam menanggulangi minimnya lapangan kerja di Indonesia. Tujuan dari program tersebut adalah: ${ }^{35}$

a. Upaya penanggulangan masalah pengangguran.

b. Melakukan pembinaan, perlindungan dan memberikan berbagai kemudahan kepada TKI dan Perusahaan Jasa Penempatan Tenaga Kerja Indonesia (PJTKI).

c. Peningkatan kesejahteraan keluarganya melalui gaji yang diterima atau remitansi.

d. Meningkatkan keterampilan TKI karena mempunyai pengalaman kerja di luar negeri.

e. Bagi Negara, manfaat yang diterima adalah berupa peningkatan penerimaan devisa, karena para TKI yang bekerja tentu memperoleh imbalan dalam bentuk valuta asing.

${ }^{35}$ http://blogkangadi.blogspot.co.id/2014/04/makalah-tentang-tki.html diakses pada tanggal 10 Juli 
Lebih lanjut didalam pasal 21 Undang-Undang nomor 39 tahun 1999 tentang HAM menyatakan bahwa, dalam hal warga negara Indonesia terancam bahaya nyata, Perwakilan Indonesia berkewajiban memberikan perlindungan, membantu, dan menghimpun mereka di wilayah yang aman, serta mengusahakan memulangkan mereka ke Indonesia atas biaya negara . Pengertian diatas adalah memberikan upaya-upaya yang dilakukan terhadap korban perdagangan orang, sertamengusahakan untuk memulangkannya ke Indonesia, dan pemerintah wajib melindungi warga negara yang menjadi korban perdagangan orang di luar negeri.

Hal-hal yang dirasa masih perlu di lakukan pemerintah Indonesia dalam penanggulangan Human Trafficking atau tindak perdagangan orang (TPPO) antara lain:

1. Dibentuk peraturan perundangan yang mampu menyentuh persoalan yang mengandung unsur asing.

2. Menetapkan sanksi yang tegas baik pidana maupun administratif terhadap nggaran atas ketentuan-ketentuan yang mendasar agar menimbulkan efek jera.

3. Rekruitment TKI dilakukan secara tepat dengan asas mudah, murah dan cepat untuk menghindarkan TKI illegal

4. Mengefektifkan sistem pengawasan pemerintah. ${ }^{36}$

Pemerintah perlu menertibkan para agen TKI ilegal untuk menghindari permasalahan sejak proses awal. Kita semua perlu menyadari bahwa permasalahan TKI berawal dari dalam negeri, meskipun akar masalah di luar negeri juga tidak bisa diabaikan. Rendahnya kesempatan kerja dan tingginya pertumbuhan penduduk sebagai akibat mengendurnya berbagai kebijakan kependudukan berdampak pada meningkatnya aliran pekerja dengan pendidikan rendah ke luar negeri. Sehingga peran serta solusi dari pemerintah sangat diperlukan dalam menangani masalah ketenagakerjaan TKI. Disamping itu Sebagai bentuk tanggung jawab atau beban moril terhadap warga negaranya, maka pemerintah mesti memperhatikan TKI atau TKW yang sedang bekerja di luar negeri. Di samping itu, peran pemerintah juga ditekan pada aspek pembinaan, perlindungan dan memberikan kemudahan-kemudahan kepada tenaga kerja tersebut dan perusahaan yang bergerak di jasa penempatan TKI. Program penempatan tenaga kerja ke luar negeri memberi manfaat dalam mengatasi pengangguran, meningkatkan keterampilan dan kesejahteraan diri serta keluarga TKI, dan peningkatan penerimaan devisa. Meskipun

36 Midah Agus., (Makalah Tenaga Kerja Indonesia), Perdagangan Manusia dan Cara penanggulangannya, Jakarta, 23 Mei 2010. 
demikian, angka kriminalitas yang dialami oleh TKI atau TKW masih tergolong tinggi. Hal ini tentu menandakan bahwa masih lemahnya perlindungan dari negara terhadap mereka.

Pelayanan dan perlindungan terhadap Warga Negara Indonesia (WNI) termasuk yang sedang berada di luar negeri merupakan amanat konstitusi sebagaimana tertuang dalam Pembukaan UUD 1945 alinea ke-IV yang menyebutkan bahwa: “...melindungi segenap bangsa Indonesia dan seluruh tumpah darah Indonesia..." sebagai salah satu tujuan nasional Indonesia. Amanat konstitusi tersebut telah dijabarkan dalam berbagai ketentuan perundang-undangan di bawahnya, antara lain UU No. 37 Tahun 1999 tentang Hubungan Luar Negeri Pasal 19 Huruf b yang memuat kewajiban Perwakilan Republik Indonesia di luar negeri untuk memberikan pengayoman, perlindungan dan bantuan hukum bagi WNI di luar negeri, sesuai dengan peraturan perundang-undangan nasional serta hukum dan kebiasaan internasional.

Demikian juga mengenai penempatan TKI di luar negeri sebaiknya hanya dapat dilakukan ke Negara tujuan yang pemerintahnya telah membuat perjanjian tertulis dengan Pemerintah RI atau ke negara tujuan yang mempunyai Peraturan Perundang-undangan yang melindungi tenaga asing. Atas pertimbangan keamanan, Pemerintah menetapkan negara-negara tertentu tertutup bagi penempatan TKI, antara lain negara tujuan dalam keadaan perang, bencana alam, atau terjangkit wabah penyakit menular.

Penempatan calon TKI/TKI di luar negeri diarahkan pada jabatan yang tepat sesuai dengan keahlian, ketrampilan, bakat, minat, dan kemampuan. Penempatan calon TKI/TKI dilaksanakan dengan memperhatikan harkat, martabat, hak azasi manusia, perlindungan hukum, pemerataan kesempatan kerja, dan ketersediaan tenaga kerja dengan mengutamakan kepentingan nasional. Setiap orang dilarang menempatkan calon TKI/TKI pada jabatan dan tempat pekerjaan yang bertentangan dengan nilai-nilai kemanusiaan dan norma kesusilaan serta Peraturan Perundang-undangan, baik di Indonesia maupun di Negara tujuan atau di negara tujuan yang telah dinyatakan tertutup.

Demikian selanjutnya penempatan TKI pada pengguna perseorangan dilakukan melalui mitra usaha di negara tujuan. Mitra Usaha berbentuk badan hukum yang didirikan sesuai dengan ketentuan di negara tujuan. Untuk pengguna perseorangan, dapat mempekerjakan TKI pada pekerjaan antara lain, sebagai penata laksana rumah tangga, pengasuh bayi atau perawat manusia lanjut usia, pengemudi, tukang kebun/taman (sektor informal). 
Perlindungan bagi calon TKI yang diberangkatkan keluar negeri oleh P3TKIS, meliputi kegiatan sebelum pemberangkatan (pra penempatan), selama masa penempatan di luar negeri, dan sampai dengan kembali ketanah air (purna penempatan). Untuk selanjutnya, TKI yang bekerja di luar negeri secara perseorangan berhak untuk memperoleh perlindungan dari Perwakilan RI dinegara yang bersangkutan.

\subsection{Upaya Peningkatan Sumber Daya Manusia TKI.}

Ada berbagai faktor penyebab yang mendorong seseorang untuk menjadi orang yang bekerja di luar negeri meninggalkan tanah airnya. Menjadi Tenaga Kerja Indonesia atau yang disingkat dengan sebutan TKI bukanlah hal yang mudah. Dibutuhkan tahapantahapan untuk bisa berangkat dan bekerja di negara asing dengan berbagai perbedaan budaya yang ada di dalamnya. Minimnya permintaan tenaga kerja di Indonesia salah satu penyebab banyak orang yang memutuskan untuk menjadi TKI baik secara legal maupun ilegal. Adapun faktor alasan penyebab seseorang menjadi TKI (Tenaga Kerja Indonesia) adalah mencari penghasilan yang lebih besar.

Pada umumnya penghasilan sebagai Tenaga Kerja Indonesia (TKI) legal alias resmi di luar negeri cukup besar jumlahnya. Apabila dibandingkan dengan penghasilan UMP (Upah minimum Provinsi) atau UMR (Upah Minimum Regional) di Indonesia, maka penghasilan seorang TKI mungkin bisa mencapai berkali-kali lipatnya. Namun demikian apabila para TKI tidak dapat menyesuaikan gaya hidupnya dengan biaya hidup di tempatnya bekerja yang pada umumnya lebih besar dibandingkan dengan di kampung halamannya, maka penghasilan besar pun akan habis juga tanpa tersisa.

Umumnya, para TKI berasal dari rumah tangga dengan kondisi ekonomi pas-pasan. Karena itu, peran remitansi dari para TKI cukup besar bagi upaya penanggulangan kemiskinan. Hasil studi yang dilakukan oleh Suhariyanto et al. juga menemukan bahwa sebagian besar sumber pendapatan rumah tangga migran, yakni rumah tangga dengan minimal satu anggota rumah tangga bekerja sebagai TKI, berasal dari remitansi. Donasinya mencapai 31,2 persen terhadap total pendapatan yang diterima oleh rumah tangga.

\section{PENUTUP}

Dari hasil pembahasan sebelumnya, maka dapat diambil kesimpulan sebagai berikut: 
1. Bahwa Tenaga Kerja Indonesia (TKI) umunya adalah sebutan bagi warga negara Indonesia yang lowlife dan unskill yang bekerja di luar negeri. TKI yang bekerja di luar negeri dapat dikelompokan menjadi TKI legal dan TKI ilegal, TKI legal adalah tenaga kerja Indonesia yang hendak mencari pekerjaan di luar negeri dengan mengikuti prosedur dan aturan serta mekanisme secara hukum yang harus ditempuh untuk mendapatkan izin bekerja di luar negeri, para pekerja juga disertai dengan surat-surat resmi yang menyatakan izin bekerja di luar negeri. Para TKI yang bekerja diluar negeri telah menyumbangan devisa yang sangat besar hingga dijuluki sebagai Pahlawan Devisa. Pengiriman uang oleh para TKI dari Luar Negeri bukan jumlah yang sedikit. Sampai Oktober 2016, remitansi tenaga kerja Indonesia (TKI) di luar negeri sebesar US\$ 7.4 miliar atau setara dengan Rp 97, 5 triliun. Sementara remitansi TKI sepanjang tahun 2015 mencapai US\$ 8,6 juta atau setara dengan Rp 119 triliun. remitansi TKI telah secara nyata menolong ketahanan perekonomian makro Indonesia, terutama perekonomian mikro di daerah-daerah sumber TKI. ${ }^{37}$ Berdasarkan data yang diperoleh dari Bank Indonesia, jumlah remitansi yang dihasilkan selalu meningkat setiap tahunnya hingga US\$ 7,5 juta / tahun. Itu berarti bahwa kiriman uang dari para TKI telah secara langsung mempengaruhi ketahanan fondasi ekonomi Indonesia melalui peredaran fresh money di daerah-daerah asal TKI dengan seluruh ikutan atau efek dominonya. Oleh karenanya bentuk perlindungan terhadap TKI yang berkerja diluar negeri harus lebih dioptimalkan lagi. Upaya perlindungan hukum bagi Tenaga Kerja Indonesia adalah merupakan perosalan yang berhadapan langsung dengan persoalan perlindungan Hak Asasi Manusia (HAM).

2. Data Badan Nasional Penempatan dan Perlindungan Tenaga Kerja Indonesia (BNP2TKI) tahun 2014 menunjukkan sekitar 5-15 \% dari 200-400 ribu orang TKI yang pulang ke Indonesia setiap tahunnya adalah TKI yang bermasalah. Masalahmasalah tersebut diantaranya berkaitan dengan legalitas keberangkatan, menjadi korban tindak kekerasan/konflik dengan majikan berupa kekerasan fisik, penganiayaan seksual, masalah tidak digaji, dan sebagainya. Data TKI yang dipulangkan selama tahun 2014 dari Arab Saudi sebanyak 20.379 orang, sedangkan dari Malaysia sebanyak 26.428 orang. Untuk mengantisipasi persoalan

37 http://www.beritasatu.com/ekonomi/406983-sampai-oktober-2016-remitansi-tki-capai-rp-975triliun.html dikases pada tanggal 15 Juni 2017 
tersebut diperlukan adanya kepastian, perlindungan hukum dan HAM yang bekerja ke luar negeri beserta keluarganya, mulai dari Pra Employment (sebelum bekerja), During Employment (selama bekerja ) dan Post Employment.(setelah selesai bekerja). Adapun sikap negara Indonesia terhadap negara-negara user (pengguna) adalah dengan jalan membuka jalur dipolomasi luar negeri dan penerapan prinsip Standar Minimum Internasional adalah hal yang wajar dilakukan oleh setiap negara terhadap warga negara lain yang berada di wilayah yurisdiksinya.

\section{DAFTAR PUSTAKA}

\section{Buku:}

Bagir Manan, 2011, Berkeadilan (Kumpulan Pemikiran) Dalam Rangka Purnabhakti Prof, Dr, $H$ Bagir Manan, SH, MCL, PSKN-HTN UNPAD-Rosda, Bandung.

Gunawan, R 2013, “Migrant Care: 256 TKI Terancam Hukuman Mati di Luar Negeri”,

Huala Adolf, 1996, Aspek-Aspek Negara dalam Hukum Internasional, RajaGrafindo Persada, Jakarta.

J.L Brierly, 1954, The Law of Nations, Oxford, Clarendon Press, edisi ke-5, Inggris.

Midah Agus., (Makalah Tenaga Kerja Indonesia), Perdagangan Manusia dan Cara penanggulangannya, Jakarta, 23 Mei 2010.

Mochtar Kusumaatmadja, 2006, Konsep-Konsep Hukum Dalam Pembangunan, Alumni, Bandung. 1982, Pengantar Hukum Internasionl, Putra Abardin, Bandung.

\section{Undang-undang:}

Konsideran Undang-Undang No.39 tahun 2004 tentang Penempatan dan Perlindungan Tenaga Kerja Indonesia di Luar Negeri

Konsideran Undang-Undang No. 13 Tahun 2003 tentang Ketenagakerjaan

Konsideran Undang-Undang No.37 Tahun 1999 tentang Hubungan Luar Negeri.

PP No.3 Tahun 2013 tentang Perlindungan Tenaga kerja Indonesia di Luar Negeri

UU No.13 tahun 2003 tentang Ketenagakerjaan

UU No.25 Tahun 2004 Tentang Sistem Perencanaan Pembangunan Nasional.

\section{Sumber Lain:}


BNP2TKI 2013, “Remitansi TKI Tahun 2013 Capai Rp 81,34

Trilyun”, ,<http://www.bnp2tki.go.id/berita-mainmenu-231/9227-remitansitki-tahun-2013-capai-rp-8134-trilyun.html>.

Suprayogi, A 2013, "Malaysia dan Arab Saudi”, Negara Kasus TKI Tertinggi, diakses http://news.liputan6.com/read/624151/malaysia-dan-arab-saudinegarakasus-tki-tertinggi

Susi Dwi Harijanti, Negara Hukum dan Ketatanegaraan (Dalam Tulisan Negara Hukum Yang Berkeadilan (Kumpulan Pemikiran) Dalam Rangka Purnabhakti Prof,Dr, H Bagir Manan, SH, MCL, Bandung, PSKN-HTN UNPADRosda,2011

BNP2TKI 2011, “Turun, Penyelesaian Kasus TKI di Arab Saudi”,

<http://www.bnp2tki.go.id/berita-mainmenu-231/3953-turun-penyelesaian-kasus-tkidiarab-saudi. html

<http://news.liputan6.com/read/786508/migrant-care-256-tkiterancam-hukuman-mati-diluar-negeri>

<http://www.lbhyogyakarta.org/2016/05/perlindungan-negara-terhadap-buruh-migran> 〈http://www.ilo.org/wcmsp5/groups/public/asiajakarta/documents/publication/wcms $>$ <http://www.lbhyogyakarta.org/2016/05/perlindungan-negara-terhadap-buruh-migran, > <http://blogkangadi.blogspot.co.id/2014/04/makalah-tentang-tki.html> <http://www.beritasatu.com/ekonomi/406983-sampai-oktober-2016-remitansi-tki-capairp-975-triliun.html> 